\title{
LA UTILIZACIÓN DE MÉTODOS CUALITATIVOS EN ENFERMERÍA
}

\author{
RICK ZOUCHA \\ RN, DNSc, CS Profesor Asistente Duquesne University
}

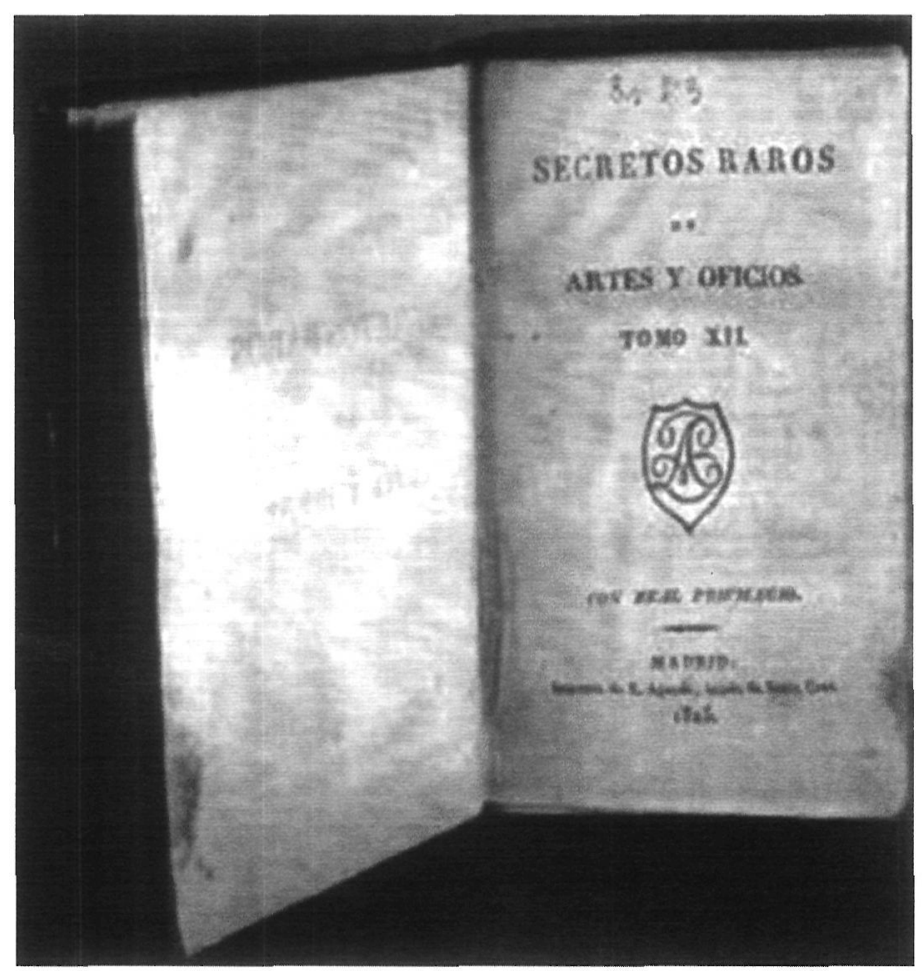

\section{INTRODUCCIÓN}

Durante las pasadas dos décadas, las personas que han realizado estudios sobre enfermería han contribuido con grandes cantidades de conocimientos que han ayudado a mejorar inmensamente la práctica clínica y los resultados de salud. Una manera de actualizar estos estudios es a través de los métodos cualitativos, los cuales han aumentado en popularidad en la disciplina de enfermería. El enfoque cualitativo en los estudios de enfermería motiva la exploración y el conocimiento de varios fenómenos clínicos en un esfuerzo por el desarrollo de estrategias para sus intervenciones. El propósito de este trabajo es el de discutir sobre los beneficios y la utilidad de llevar a cabo investigaciones cualitativas y el de presentar cuatro de estos métodos frecuentemente usados en enfermería.

\section{USING QUALITATIVE METHODS IN NURSING RESEARCH}

\section{SUMMARY}

Over the two past decades, nursing researchers have contributed vast amounts of knowledge that have improved clinical practice and health outcomes immensely. One approach to research is through qualitative methods, which has recently gained much popularity within the discipline of nursing. Qualitative approaches to nursing research encourage the exploration and understanding of various clinical phenomena in an effort to develop strategies for intervention. The purpose of this paper is to discuss the benefits and usefulness of conducting qualitative research studies and to present an overview of four types of qualitative research methods frequently used in nursing. 


\section{¿QUÉ ES LA INVESTIGACIÓN CUALITATIVA?}

La Investigación Cualitativa, según Polit \& Hungler (1997), es la investigación de un fenómeno particular realizada usualmente con profundidad y de una forma holística a través de la recogida de información narrativa valiosa usando un diseño de investigación flexible. Los métodos cualitativos de investigación promueven el propósito de estudio a través de la identificación, descripción, exploración y explicación del fenómeno estudiado (Polit \& Hungler, 1997). Una definición sencilla de investigación cualitativa es que este tipo de estudio utiliza información de texto (en forma de transcripciones de entrevistas, textos, cartas) para analizar el significado del fenómeno de interés desde la perspectiva de los mismos participantes del estudio, mientras se reconoce que el análisis está construido basándose en la interpretación del investigador. Field \& Morse (1985) describió los métodos de investigación cualitativa como métodos útiles cuando se describe el fenómeno desde la perspectiva emic. Leininger (1990) describió el paradigma de la investigación cualitativa como " los métodos y técnicas de observación, documentación, análisis e interpretación de atributos, pautas, rasgos y significados de las características contextuales o gestálticas del fenómeno estudiado." Morse (1992) apoyó estas descripciones y añadió que el método de investigación cualitativo puede ser caracterizado por tres aspectos: perspectiva emic, perspectiva holística y procesos inductivos e interactivos de investigación. Ella describió la perspectiva emic como extractora de significados, experiencias y percepciones desde el punto de vista del participante frente a aquella del investigador o la perspectiva dominante en el mundo. La perspectiva holística de la investigación cualitativa se logra cuando se consideran e incluyen los valores y contextos secundarios del fenómeno objeto de estudio (Morse, 1992).

A veces existe confusión con respecto al significado del termino métodos de investigación cualitativos. Los estudios cualitativos son descritos con frecuencia como "inductivos", lo cual es engañoso. En realidad, los métodos de estudio cualitativo combinan la inducción con la deducción según transcurra el proceso de investigación. El proceso interactivo e inductivo entre la persona que realiza el estudio y la información recogida permite al investigador poder comprender y conocer mejor el fenómeno que se esté estudiando (Morse, 1992). A los estudios cualitativos se les denomina con frecuencia "primer nivel" de estudio, que dirigen hacia pruebas cuantitativas los hallazgos cualitativos. Aunque se piensa que los hallazgos de los estudios cualitativos son probados a menudo utilizando enfoques cuantitativos, este no siempre ocurre así. De hecho, algunos estudios cualitativos se han verificado a través de más estudios cualitativos (Olshansky, 1996).

\section{MÉTODOS DE INVESTIGACIÓN CUALITATIVOS EN ENFERMERÍA}

Para el propósito de este trabajo, los cuatro métodos de investigación cualitativa más importantes son discutidos en relación con su utilidad para llevar a cabo estudios de investigación en enfermería. Esta discusión incluirá los siguientes métodos: etnoenfermería, etnografía, teoría fundamentada (grounded theory) y fenomenología.

\section{MÉTODO ETNOENFERMERO}

La metodología de investigación etnoenfermera fue desarrollada e presentada en los años 1960 por Madeleine Leininger (1978). Leininger (1990) definió la etnoenfermería como "el estudio, documentación y análisis, desde una perspectiva local o emic del punto de vista de las personas, las creencias y las prácticas sobre fenómenos potenciales o actuales de cuidados de enfermería dentro de una cultura particular para generar conocimiento enfermero" (p. 46). El propósito más importante del método de investigación etnoenfermero es instituir un método de descubrimiento naturalista y emic abierto para explicar y estudiar los fenómenos relacionados con la Teoría de la Diversidad y la Universalidad de los Cuidados Culturales de Leininger (1991). De acuerdo con Leininger (1991), el mayor atributo del método etnoenfermero es la habilidad de ayudar al investigador en la documentación sistemática de los significados y experiencias en la vida de las personas en relación con el cuidado, la salud y el bienestar del ser humano. El método etnoenfermero de Leininger (1991) comparte elementos comunes sugeridos en los tres métodos cualitativos: etnografía, fenomenológica, y teoría fundamentada. El método etno- 
enfermero une los aspectos comunes de los métodos con la singularidad de un método que busca descubrir fenómenos de enfermería.

Además del método de investigación etnoenfermero, Leininger (1990) ha desarrollado las cuatro fases de análisis de información cualitativa apropiadas para el análisis de la información al usar este método. Leininger (1991) describió cuatro fases de análisis de información cualitativa. En la primera fase el investigador reúne, describe, cataloga y comienza a analizar la información relacionada a las preguntas del estudio. La primera fase también incluye observaciones, la identificación del significado del contexto, a la vez que se realizan interpretaciones y se identifican símbolos.

La segunda fase está enfocada hacia la identificación y categorización de descriptores y componentes. En esta fase la información está codificada y clasificada con relación al área de estudio y a las preguntas de estudio. Los descriptores emic y etic son estudiados para determinar sus semejanzas y diferencias. Los componentes recurrentes son estudiados para entender su significado.

En la tercera fase de análisis de información el investigador busca patrones y el análisis contextual. La información es examinada para descubrir saturación de ideas y patrones recurrentes de significados, expresiones y formas similares y diferentes. La información también es examinada para extraer "significados dentro del contexto" y credibilidad. La cuarta y última fase está enfocada hacia la identificación de los temas de mayor importancia, los descubrimientos de la investigación, las formulaciones teóricas y las recomendaciones.

Muchos investigadores en enfermería han utilizado la etnoenfermería en sus propios estudios. Algunos ejemplos de investigadores en etnoenfermería incluyen a McFarland (1997), Zoucha (1998) y Berry (1999).

\section{MÉTODO ETNOGRÁFICO}

De acuerdo con Patton (1990), la noción de cultura es esencial para la etnografía. La observación participante y el trabajo de campo son formas distintas de dirigir el enfoque de la investigación hacia la interpretación y la aplicación de los hallazgos dentro del contexto de una cultura específica. Históricamente, las raíces de la etnografía están en la antropología cultural, y recientemente ha sido utilizada por enfermeras y otros estudiosos de la salud (Boyle, 1994). La etnografía está considerada como holística, y el análisis de la información implica la contextualización de las observaciones y entrevistas del investigador desde una perspectiva cultural más amplia. La meta final de la etnografia es la de comprender la perspectiva del informante (emic) y su experiencia de la realidad (Boyle, 1994).

Agar (1986) apoya la noción de Boyle de etnografía y sugiere que las etnografías surgen de la relación entre el etnógrafo, el grupo que es estudiado y el público al que se destina. El proceso de investigación etnográfico es interpretador y es mediador entre dos mundos a través de la interpretación de un tercero (Agar, 1986). Para las enfermeras investigadoras, la etnografía puede convertirse en un proceso natural y cómodo debido a la naturaleza holística compartida por la enfermería y por el método. La etnografía es un método y un proceso que permite el acceso a las creencias y a las prácticas culturales de salud y permite al investigador observar y participar en el fenómeno en el contexto cultural cuándo y dónde tenga lugar. Los etnógrafos adoptan la filosofía de que los investigadores no estudian a las personas sino que aprenden de ellas (Morse \& Field, 1995).

En resumen, la investigación etnográfica enfermera está enfocada hacia las preguntas descriptivas tales como descubrir aspectos desconocidos sobre los valores y las creencias culturales y las prácticas de salud particulares de ciertos grupos culturales seleccionados. El método preferido para aprender de las personas está basado en el uso de entrevista, observación, participación y notas de campo sin estructura. Otras fuentes de aprendizaje de las personas incluyen las actas de nacimiento y defunción, documentos, tablas, fotografias, videos, genealogías y mapas históricos (Morse \& Field, 1995). El aprender de las personas utilizando las maneras descritas anteriormente le ofrecen al investigador un conocimiento muy valioso que le ayuda a comprender la cultura desconocida de los individuos, las familias y las comunidades. El propósito principal es comprender el punto de vista emic o interno atribuido a lo desconocido para la enfermería. 


\section{METODOLOGÍA DE LA TEORÍA FUNDAMENTADA (GROUNDED THEORY)}

La teoría fundamentada es un método cualitativo particular que fue desarrollado originalmente por Glaser y Strauss (1967), basado en la estructura socio-psicológica del interaccionismo simbólico (Blumer, 1967), con sus raíces en los trabajos de George Herbert Mead (1934). El aspecto filosófico del pragmatismo está internamente relacionado a la estructura de la interacción simbólica, donde los significados se construyen sobre la base de la utilidad que encuentren los individuos. De acuerdo con el interaccionismo simbólico, las personas construyen significados en base a sus interpretaciones de las interacciones que tengan con otros (Blumer, 1969). El método de la teoría fundamentada busca descubrir el significado que las personas construyen para explicar los fenómenos de interés.

La teoría fundamentada ha sido desarrollada y refinada por Schatzman (1991), quien recientemente desarrolló el término "análisis dimensional," para reflejar el proceso cognitivo que el investigador/analista engrana mientras busca significados en la información recogida. La teoría fundamentada ha sido utilizada por varios estudios enfermeros; una pequeña parte de ellos incluye a Benoleil (1983), Corbin (1987), Wilson (1983), Hutchinson (1984), Kearney, Murphy, y Rosenbaum (1994), May (1980), y Olshansky (1987).

El método de la teoría fundamentada implica la recogida de información cualitativa a través de entrevistas semiestructuradas, a través de textos, cartas, o a través de la observación del participante. A la vez que se recoge toda la información, el investigador comienza a analizar los datos, buscando códigos o categorías que reflejen el significado de la información. Estos códigos o categorías iniciales dirigen la recogida futura de información para que esté más encauzada. Finalmente, cuanta más información se recoge, ciertos códigos siguen siendo apoyados por la información. Se puede decir que estos códigos se convierten en códigos verificados y saturados por la recogida continua de información. Además, la relevancia de estos códigos comienza a mostrarse aparente cuando son integrados con otros códigos o categorías específicas. A medida que el proceso de recogida de datos y análisis se va desarrollando, una o varias categorías clave son construidas, y estas categorías son integradas entre sí al igual que con otras categorías inferiores, formando finalmente una estructura teórica principal que explica el significado del fenómeno en cuestión. Esta estructura teórica puede tener la forma de un proceso social básico (Glasea, 1978), reflejando un proceso que envuelve a los participantes del estudio en relación con el manejo del fenómeno de interés. Esta estructura teórica puede tener la forma de una trayectoria (Strauss, 1987) que refleja la experiencia del participante del estudio en relación con el fenómeno de interés.

En la teoría fundamentada, la información es analizada a través de un proceso llamado "análisis comparativo constante", donde la información es comparada con otras al igual que con literatura e información experimental existente del investigador. Es decir, la información siempre está siendo comparada con otra información al igual que con las experiencias personales de uno mismo en el mundo "real." El proceso de análisis incluye varios pasos, los cuales no son uniformes pero sí representan un patrón progresivo para refinar el análisis. Este proceso incluye codificación abierta, codificación axial, codificación selectiva e integración teórica. La codificación abierta es el primer paso. En este paso el investigador busca todas las palabras o códigos que puedan reflejar el significado en la información. La codificación axial es el proceso donde los códigos son "fracturados" para cotejar las condiciones y consecuencias dentro de ellos. La codificación selectiva tiene lugar cuando el proceso de codificación abierta se torna más refinado a través de la recogida de información. Durante este proceso algunos códigos son descartados debido a que no existe suficiente información para apoyarlos, mientras que se enfoca selectivamente en otros a medida que surge más información que apoye su presencia. Finalmente estos códigos seleccionados son integrados para formar el comienzo de una sustancial teoría fundamentada.

El resultado de un estudio de teoría fundamentada es la construcción de una teoría que está fundamentada en la información, por lo tanto se le llama "teoría fundamentada". A esta teoría inicial se le llama teoría "sustancial" por el hecho de que explica un área particular sustancial (el fenómeno 
de interés). Finalmente, una teoría sustancial puede ser desarrollada para convertirse en teoría "formal", una que trasciende el campo sustancial específico y se aplica a muchas áreas sustanciales. Por ejemplo, el trabajo de Olshansky (1987, 1996) sobre la identidad como infértil es una teoría probada sustancial. Si este trabajo fuese extendido a otros campos sustanciales además de la infertilidad, como pudiese ser el campo de las enfermedades crónicas, y la teoría de identidad se pudiese aplicar, entonces se estaría construyendo el comienzo una teoría formal.

\section{FENOMENOLOGÍA}

En realidad la fenomenología es tanto un enfoque filosófico como un método de investigación. El método de investigación está fundamentado en los pilares esenciales filosóficos de la fenomenología. El método de fenomenología proporciona una guía para el estudio de la manera que las personas describen las cosas y su experiencia a través de sus sentidos. El enfoque de este método se centra en la manera en que las personas construyen los fenómenos que viven, y como le dan un significado para que les moldee el mundo entono a ellos, para así crear una perspectiva del mundo desde la experiencia (Patton, 1990). El propósito de la fenomenología es comprender las experiencias humanas. La filosofía fenomenológica se basa en los trabajos de Husserl y Heidegger (Morse \& Field, 1995), se basa en la creencia de que las personas experimentan su mundo basándose en sus propias interpretaciones de sus experiencias. Van Manen (1990) describió cuatro factores existenciales que sirven como guías en las experiencias fenomenológicas y para la realización de estudios. En estos cuatro factores se incluyen el espacio vivido, el cuerpo vivido, el tiempo vivido, y la relación humana vivida. El espacio vivido hace referencia al entorno o al sentido de espacio. El cuerpo vivido hace referencia a la manera en que uno percibe su propio cuerpo o funciones del cuerpo. El tiempo vivido hace referencia al sentido que tiene una persona de estar en un determinado momento, incluyendo la manera que percibe el pasado, presente y futuro. Las relaciones humanas vividas hace referencia a las relaciones interpersonales y el nivel al que uno experimenta un sentido de comunidad con otros.
Este método fenomenológico de investigación cualitativa busca comprender como las personas perciben su mundo y le dan un significado; es decir, busca comprender las experiencias vividas de las personas que están siendo estudiadas. El método fenomenológico permite que el investigador no solamente describa sino que también interprete las experiencias vividas por las personas. El método fenomenológico es importante y útil para estudios de enfermería porque permite que el investigador descubra los significados de las experiencias humanas en salud y en enfermedad y ayuda a que las enfermeras puedan comprender e interpretar estas experiencias (Ray, 1994).

De forma similar a la metodología de teoría fundamentada, el enfoque fenomenológico de investigación utiliza un proceso continuo de recogida y análisis de información. El análisis de los datos tiene lugar con la recogida inicial de información, con una recogida continua de información que está influida y más delimitada por éste.

Muchos investigadores de enfermería han utilizado la fenomenología en sus propios estudios. Algunos ejemplos de estudios enfermeros fenomenológicos incluyen a Benner (1994), Tanner (1993), C.T. Beck (1996), Winter y Lockhart (1997), y Lockhart (1990).

\section{¿POR QUÉ UTILIZAR EL ENFOQUE CUALITATIVO DE INVESTIGACIÓN?}

La investigación cualitativa es muy apropiada para estudios de investigación enfermeros, en particular desde que las enfermeras se dedican a observar las respuestas humanas y a cómo proporcionar cuidados empáticos a personas dentro de sus culturas y contextos psicosociales específicos. Los diversos métodos de investigación cualitativa descritos en este artículo proporcionan ejemplos de cómo los estudios de enfermería pueden descubrir, destapar, y explicar de forma efectiva tales respuestas humanas. La investigación cualitativa también sirve para generar teorías o explicaciones que podrán ser probadas a través de futuras investigaciones. Es importante llegar a decisiones metodológicas basadas en la pregunta principal del estudio, y desde que muchas preguntas de investigación en enfermerías implican la exploración de experiencias y significados humanos, los métodos cualitativos a menudo son los mas apropiados para la investigación enfermera. 


\section{BIBLIOGRAFÍA}

Agar, M. H. (1986) Speaking of ethnography. Qualitative Research methods series 2. Newbury Park, CA: Sage.

Beck, C.T. (1996) Postpartum depressed mothers' experiences interacting with their children. Nursing Research, 45 (2), 98-104.

Benner, P. (1994) The tradition and skill of interpretive phenomenology. Thousand Oaks, CA: Sage.

Benoliel, J.A. (1983) Grounded theory and qualitative data: The socializing influence of life-threatening disease on identity development. In P.J. Wooldridge, M.H. Scmitt, J.K. Skipper, \& R.C. Leonard (Eds.) Behavioral science and nursing theory (pp. 141-187). St. Louis, MO: C.V. Mosby. Blumer, H. (1969) Symbolic interactionism: Perspective and method. New York: PrenticeHall.

Boyle, J. (1994).Styles of ethnography. In J. M. Morse (Ed.), Qualitative health research (pp. 20-30). Newbury Park, CA: Sage.

Corbin, J. M. (1987) Women's perceptions and management of a pregnancy complicated by chronic illness. Health Care for Women International, 8, 317-337.

Glaser, B.G. (1978) Theoretical sensitivity. Mill Valley, CA: The Sociology Press.

Glaser, B.G., Strauss, A.L. (1967) The discovery of grounded theory. Chicago: Aldine Publications. Hutchinson, S.A. (1984) Creating meaning: A grounded theory of NICU nurses. Nursing Outlook, 32(2), 86-90.

Kearney, M. H., Murphy, S., Rosenbaum, M. (1994) Learning by losing: Sex and fertility on crack cocaine. Qualitative Health Research, 4, 142-162.

Leininger, M. M., (1990) Ethnomethods: The philosophical and epistemic bases to explicate transcultural nursing knowledge. Journal of Transcultural Nursing, 1, 2, 40-51.

Lockhart, J.S. (1990) Administering an injection. Nurse Educator, 14 (5), 7.

May, K.A. (1980) A typology of detachment/involvement styles adopted during pregnancy by first time expectant fathers. Western Journal of Nursing Research, 2, 443-45.

Mead, G. H. (1934) Mind, self, and society. Chicago: University of Chicago Press.
Morse, J. M. (1992) Qualitative health research. Newbury Park, CA: Sage.

Morse, J.M., Field, P.A. (1995) Qualitative reseasrch methods for health professionals, 2nd edition. Thousand Oaks, CA: Sage.

Olshansky, E. (1987) Identity of self as infertile: An example of theory-generating research. Advances in Nursing Science, 9 (2) 54-63.

Polit, D. F., Hungler, B. P., (1997) Essentials of nursing research: Methods, appraisals, and utilization. (4th ed.). Philadelphia: Lippincott.

Ray, M.A. (1994) The richness of phenomenology: Philosophic, theoretic and methodologic concerns. In J.M. Morse (Ed.), Critical Issues in Qualitative Research Methods. Thousand Oaks, CA: Sage.

Schatzman, L. (1991) Dimensional analysis: Notes on an alternative approach to the grounding of theory in qualitative research. In Maines, D. (Eds.), Social Organization and Social Process. New York: Aldine De Gruyter.

Strauss, A.L. (1987) Qualitative analysis for social scientists. Cambridge: Cambridge University Press.

Tanner, L., Benner, P., Chesla, C., Gordon, D., (1993) The phenomonology of Knowing a patient. Image: The Journal of Nursing Scholarship, 25, 4, 273-280.

Van Manen, M. (1990) Researching lived experiences: Human science for an action sensitive pedagogy. London, Ontario: Althouse.

Wilson, H.S. (1983) Usual hospital treatment in the United Sates community mental health system: A dispatching process. International Journal of Nursing Studies, 20, 75-82.

Winter, M.K. and Lockhart, J.S. (1997) From motivation to action: Understanding nurses' political involvement. Nursing \& Health Care: Perspectives on Community, 18, 244-250.

Zoucha, R.D., (1998) The experiences of MexicanAmericans receiving professional nursing care: An ethnonursing study. Journal of Transcultural Nursing., 9:2, 34-44.

\section{INTRODUCTION}

Over the past two decades, nursing researchers have contributed vast amounts of knowledge 
that have improved clinical practice and health outcomes immensely. One approach to research is through qualitative methods, which has recently gained much popularity within the discipline of nursing. Qualitative approaches to nursing research encourage the exploration and understanding of various clinical phenomena in an effort to develop strategies for intervention. The purpose of this paper is to discuss the benefits and usefulness of conducting qualitative research studies and to present an overview of four types of qualitative research methods frequently used in nursing.

\section{WHAT IS QUALITATIVE RESEARCH?}

Qualitative research according to Polit \& Hungler (1997) is the investigation of a particular phenomena usually conducted in an in-depth and holistic manner, through the collection of rich narrative data using a flexible research design. Qualitative research methods promote the purpose of research through identification, description, exploration and explanation of the phenomena under study (Polit \& Hungler, 1997). A simple definition of qualitative research is that this type of research uses textual data (in the form of transcripts of interviews, text, letters) to analyze the meaning of phenomena of interest from the perspective of the research participants themselves, while recognizing that the analysis is constructed based on the interpretation of the researcher. Field \& Morse (1985) described qualitative research methods as useful when describing the phenomena from the emic perspective. Leininger (1990) described the qualitative research paradigm as "the method and techniques of observing, documenting, analyzing, and interpreting attributes, patterns, characteristics, and meanings of specific contextual or gestaltic features of phenomena under study." Morse (1992) supported these descriptions and added that the qualitative research method can be characterized by three features: emic perspective, holistic perspective and inductive and interactive process of inquiry. She described the emic perspective as eliciting meaning, experiences and perceptions from the participants' point of view, versus that of the researcher or the dominant world view. The holistic perspective of qualitative research is achieved by considering and including the underlying values and context of the particular phenomena being studied (Morse, 1992). Confusion sometimes exists regarding what is meant by the term qualitative research methods. Qualitative research is often termed "inductive," which is misleading. In actuality, qualitative methods combine induction and deduction as the process of research continues. The inductive and interactive process between the researcher and data allows the researcher to comprehend and gain insight into the phenomena under study (Morse, 1992). Qualitative research is often termed "first level" of study, leading to quantitative testing of qualitative findings. While findings of qualitative studies are often tested out by using quantitative approaches, this is not always the case. In fact, some qualitative studies have been verified through further qualitative studies (Olshansky, 1996).

\section{TYPES OF QUALITATIVE RESEARCH METHODS USED IN NURSING}

For the purposes of this paper, four major qualitative research methods are discussed in relation to their usefulness in conducting nursing research. This discussion will include the following methods: ethnonursing, ethnographic, grounded theory and phenomenology.

\section{ETHNONURSING METHOD}

Ethnonursing research methodology was developed and introduced in the 1960's by Madeline Leininger (1978). Leininger (1990) defined ethnonursing "as the study, documentation, and analysis of the local or emic people's viewpoints, beliefs, and practices about actual or potential nursing care phenomena within a particular culture to generate nursing knowledge" (p. 46). The major purpose of the ethnonursing research method is to institute a naturalistic and (emic) open discovery method to explain and study nursing phenomena related to Leininger's (1991) theory of Culture Care Diversity and Universality. According to Leininger (1991) the major feature of the ethnonursing method is the ability to assist the researcher in the systematic documentation of the meaning and experiences in people's lives as related to human care, health and well being. Leininger's (1991) ethnonursing method shares common elements suggested in the three qualitati- 
ve methods of ethnography, phenomenology and grounded theory. The ethnonursing method blends the commonalties of the methods with the uniqueness of a method that seeks to uncover nursing phenomena.

In addition to the ethnonursing research method, Leininger (1990) has developed the Four Phases of qualitative data analysis appropriate to analyze date using this method. Leininger (1991) described four phases of qualitative data analysis. In the first phase the researcher collects, describes, records and begins to analyze data related to the questions of the study. Phase one also included observations, identifying contextual meaning, making interpretations and identifying symbols.

Phase two focuses on identification and categorization of descriptors and components. In this phase data are coded and classified as related to the domain of inquiry and research questions. Emic and etic descriptors are studied for similarities and differences. Recurrent components are studied for their meaning.

In the third phase of data analysis the researcher searches for patterns and contextual analysis. Data are scrutinized to discover saturation of ideas and recurrent patterns of similar and different meanings, expression and form. Data are also examined for meaning-in-context and credibility. The fourth and final phase focuses on identification of major themes, research findings, theoretical formulations and recommendations.

Many nursing researchers have used ethnonursing in their own research. A few examples of ethnonursing researchers include McFarland (1997), Zoucha (1998), Nahas \& Amasheh (1999).

\section{ETNOGRAPHIC METHOD}

According to Patton (1990) the notion of culture is essential to ethnography. Participant observation and fieldwork are the distinct approaches that focus on interpreting and applying the findings of a study within the context of a given culture. Historically, ethnography is rooted in cultural anthropology, and has more recently been used by nursing and other health care researchers (Boyle, 1994). Ethnography is considered holistic, and analysis of the data involves contextualizing the researcher's observations and interviews into a larger cultural perspective. The overall goal of ethno- graphy is to understand the informant's (emic) perspective and experience of reality (Boyle, 1994).

Agar (1986) supports Boyle's notion of ethnography and suggests that ethnographies emerge out of the relationship between ethnographer, the group being studied and the intended audience. The ethnographic research process is interpretive and mediates two worlds through the interpretative process of a third (Agar, 1986). For nurse researchers, ethnography can become natural and enjoyable process because of the shared holistic nature of nursing and the method. Ethnography is a method and process which allows access to the cultural health beliefs and practices and allows the researcher to observe and participate in the phenomena in the cultural context when and where it occurs. Ethnographers espouse the philosophy that researchers do not study people but learn from the people (Morse \& Field, 1995).

In summary, ethnography nursing research focuses on descriptive questions such as seeking the unknown about cultural values, beliefs and particular health practices of select cultural groups. The preferred method of learning from the people is through the use of unstructured interviews, observation, participation and fieldnotes. Other sources of learning from the people include birth and death records, documents, charts, photographs, videos, genealogies and historical maps (Morse \& Field, 1995). Learning from the people using the above sources offer the researcher rich knowledge in order to understand the cultural unknown of individuals, families and communities. The main goal is to understand the emic or insider view regarding the unknown to nursing.

\section{GROUNDED THEORY METHODOLOGY}

Grounded Theory is a particular qualitative method that was originally developed by Glaser and Strauss (1967), based on the social-psychological framework of symbolic interactionism (Blumer, 1969), rooted in the work of George Herbert Mead (1934). The philosophical approach of pragmatism underlies the symbolic interaction framework, wherein meaning is constructed based on the usefulness to individual persons. According to symbolic interactionism, persons construct meanings based upon their interpretations of the inte- 
ractions they have with others (Blumer, 1969). The grounded theory method seeks to discover the meaning that persons construct to explain phenomena of interest.

Grounded theory has been further developed and refined by Schatzman (1991), who has recently coined the term "dimensional analysis," to reflect the cognitive process that the researcher/analyst engages in while seeking to find meaning in the data. Grounded theory has been conducted by numerous nurse researchers, a small portion of whom include Benoliel (1983), Corbin (1987), Wilson (1983), Hutchinson (1984), Kearney, Murphy, and Rosenbaum (1994), May (1980), and Olshansky (1987).

The method of grounded theory involves collecting qualitative data through semi-structured interviews, through texts, through letters, or through participant observation. As data are collected, the researcher begins to analyze the data, searching for codes or categories that reflect the meaning in the data. These initial codes or categories direct further data collection to become more focused. Eventually, as more data are collected, selected codes continue to be supported by the data. These codes can be said to become verified and saturated by ongoing data collection. In addition, the relevance of these codes begins to become apparent, as they are integrated with other selected codes or categories. As the process of data collection and analysis continues, a core category or a few core categories are constructed, and these categories are integrated with one another as well as with other sub-categories, eventually forming a beginning theoretical framework that explains the meaning of the phenomenon in question. This theoretical framework may be in the form of a basic social process (Glaser, 1978), reflecting a process engaged in by the research participants in relation to managing the phenomenon of interest. This theoretical framework may be in the form of a trajectory (Strauss, 1987) that reflects the experience of the research participant in relation to the phenomenon of interest.

In grounded theory, data are analyzed using a process referred to as "constant comparative analysis," wherein data are compared with other data as well as with existing literature and with experiential data of the researcher. In other words, data are constantly being compared with data as well as with one's experiences in the "real" world. The process of analysis includes several steps, which are not uniformly linear but do represent a progression in refining the analysis. This process includes open coding, axial coding, selective coding, and theoretical integration. Open coding is the first step, in which the researcher searches for any and all words or codes that may reflect the meaning in the data. Axial coding is a process wherein the codes are "fractured" to look at the conditions and consequences within them. Selective coding occurs when the open coding process becomes more refined with further data collection. During this process some codes are discarded because there is not enough data to support them, while others are selectively focused upon as further data continues to support their presence. Eventually these selected codes are integrated to form a beginning substantive, grounded theory.

The outcome of a grounded theory study is the construction of a theory that is grounded in the data, hence the name "grounded theory." This initial theory is referred to as a "substantive" theory in that it explains a particular substantive area (the phenomenon of interest). Eventually, a substantive theory can be developed into a "formal" theory, one that transcends the specific substantive area and applies to many substantive areas. For example, Olshansky's $(1987,1996)$ work on identity as infertile is a substantive grounded theory. If this work were extended to other substantive areas besides infertility, such as the area of chronic illness, and if the theory of identity applied, then a beginning formal theory would be constructed.

\section{PHENOMENOLOGY}

Phenomenology is actually both a philosophical approach and a research method. The research method is founded on the philosophical underpinnings of phenomenology. The method of phenomenology is provides guidance for the study of how people describe things and experience them through their senses. The focus of this method centers on how persons construct the phenomena they experience, and ascribe meaning to the world around them and, formulate a worldview from that experience (Patton, 1990). The purpose of phenomenology is to understand human experience. The 
philosophy of phenomenology is rooted in the work of Husserl and Heidegger (Morse \& Field, 1995), based on the belief that persons experience their world based upon their own perceptions of their lived experiences. Van Manen (1990) described four existentials that serve as guides in phenomenological experience and in conducting research. These four existentials include lived space, lived body, lived time, and lived human relation. Lived space refers to the environment or the sense of spatiality. Lived body refers to how one perceives his or her own body and bodily functions. Lived time refers to a person's sense of being in time, including how one perceives past, present, and future. Lived human relation concerns interpersonal relations and the degree to which one experiences a sense of community with others.

This phenomenological method of qualitative research seeks to understand how persons experience their world and ascribe meaning to it; that is, it seeks to understand the lived experience of the persons being studied. The phenomenological method allows the researcher to not only describe, but interpret lived experiences of people. The phenomenological method is important and useful for nursing inquiry because it allows the researcher to uncover the meaning of the human experience in health and illness and assists nurses in understanding and interpreting these experiences (Ray, 1994).

Similar to grounded theory methodology, the phenomenological approach to research involves an ongoing process of data collection and analysis. Data analysis occurs upon initial data collection, with ongoing data collection influenced by and becoming more focused based on ongoing data analysis.

Many nursing researchers have used phenomenology in their own research. A few examples of phenomenological nursing research include Benner (1994), Tanner (1993), C.T. Beck (1996), Winter and Lockhart (1997), and Lockhart (1990).

\section{WHY USE QUALITATIVE APPROACHES TO RESEARCH?}

Qualitative research is very appropriate for many nursing research studies, particularly since nurses are concerned with human responses and how to provide empathic care to persons within their specific cultural and psychosocial contexts. The various qualitative research methods described in this article provide examples of how nursing research can effectively discover, uncover, and explain such human responses. Qualitative research also serves to generate theories or explanations that can then be tested through further research. It is important to make methodological decisions based on the research question, and since many nursing research questions do involve exploration of human experiences and meanings, qualitative research methods are often most appropriate for nursing research.

\section{REFERENCES}

Agar, M. H. (1986). Speaking of ethnography. Qualitative Research methods series 2. Newbury Park, CA: Sage.

Beck, C.T. (1996). Postpartum depressed mothers' experiences interacting with their children. Nursing Research, 45 (2), 98-104.

Benner, P. (1994). The tradition and skill of interpretive phenomenology. Thousand Oaks, CA: Sage.

Benoliel, J.A. (1983). Grounded theory and qualitative data: The socializing influence of lifethreatening disease on identity development. In P.J. Wooldridge, M.H. Scmitt, J.K. Skipper, \& R.C. Leonard (Eds.), Behavioral science and nursing theory (pp. 141-187). St. Louis, MO: C.V. Mosby.

Blumer, H. (1969). Symbolic interactionism: Perspective and method. New York: PrenticeHall.

Boyle, J. (1994). Styles of ethnography. In J. M. Morse (Ed.), Qualitative health research (pp. 20-30). Newbury Park, CA: Sage.

Corbin, J. M. (1987). Women's perceptions and management of a pregnancy complicated by chronic illness. Health Care for Women International, 8, 317-337.

Glaser, B.G. (1978). Theoretical sensitivity. Mill Valley, CA: The Sociology Press.

Glaser, B.G., Strauss, A.L. (1967). The discovery of grounded theory. Chicago: Aldine Publications.

Hutchinson, S.A. (1984). Creating meaning: A grounded theory of NICU nurses. Nursing Outlook, 32(2), 86-90. 
Kearney, M. H., Murphy, S., Rosenbaum, M. (1994). Learning by losing: Sex and fertility on crack cocaine. Qualitative Health Research, 4, 142-162.

Leininger, M. M., (1990). Ethnomethods: The philosophical and epistemic bases to explicate transcultural nursing knowledge. Journal of Transcultural Nursing, 1, 2, 40-51.

Lockhart, J.S. (1990). Administering an injection. Nurse Educator, 14 (5), 7.

May, K.A. (1980). A typology of detachment/involvement styles adopted during pregnancy by first time expectant fathers. Western Journal of Nursing Research, 2, 443-45.

Mead, G. H. (1934). Mind, self, and society. Chicago: University of Chicago Press.

Morse, J. M. (1992). Qualitative health research. Newbury Park, CA: Sage.

Morse, J.M., Field, P.A. (1995). Qualitative reseasrch methods for health professionals, 2nd edition. Thousand Oaks, CA: Sage.

Olshansky, E. (1987). Identity of self as infertile: An example of theory-generating research. Advances in Nursing Science, 9 (2) 54-63.

Polit, D. F., Hungler, B. P., (1997). Essentials of nursing research: Methods, appraisals, and utilization. (4th ed.). Philadelphia: Lippincott.

Ray, M.A. (1994). The richness of phenomenology: Philosophic, theoretic and methodologic concerns. In J.M. Morse (Ed.), Critical Issues in Qualitative Research Methods. Thousand Oaks, CA: Sage.

Schatzman, L. (1991). Dimensional analysis: Notes on an alternative approach to the grounding of theory in qualitative research. In Maines, D. (Eds.), Social Organization and Social Process. New York: Aldine De Gruyter.

Strauss, A.L. (1987). Qualitative analysis for social scientists. Cambridge: Cambridge University Press.

Tanner, L., Benner, P., Chesla, C., Gordon, D., (1993). The phenomonology of Knowing a patient. Image: The Journal of Nursing Scholarship, 25, 4, 273-280.

Van Manen, M. (1990). Researching lived experiences: Human science for an action sensitive pedagogy. London, Ontario: Althouse.

Wilson, H.S. (1983). Usual hospital treatment in the United Sates community mental health system: A dispatching process. International Journal of Nursing Studies, 20, 75-82.

Winter, M.K. and Lockhart, J.S. (1997). From motivation to action: Understanding nurses' political involvement. Nursing \& Health Care: Perspectives on Community, 18, 244-250.

Zoucha, R.D., (1998). The experiences of Mexican-Americans receiving professional nursing care: An ethnonursing study. Journal of Transcultural Nursing., 9:2, 34-44.

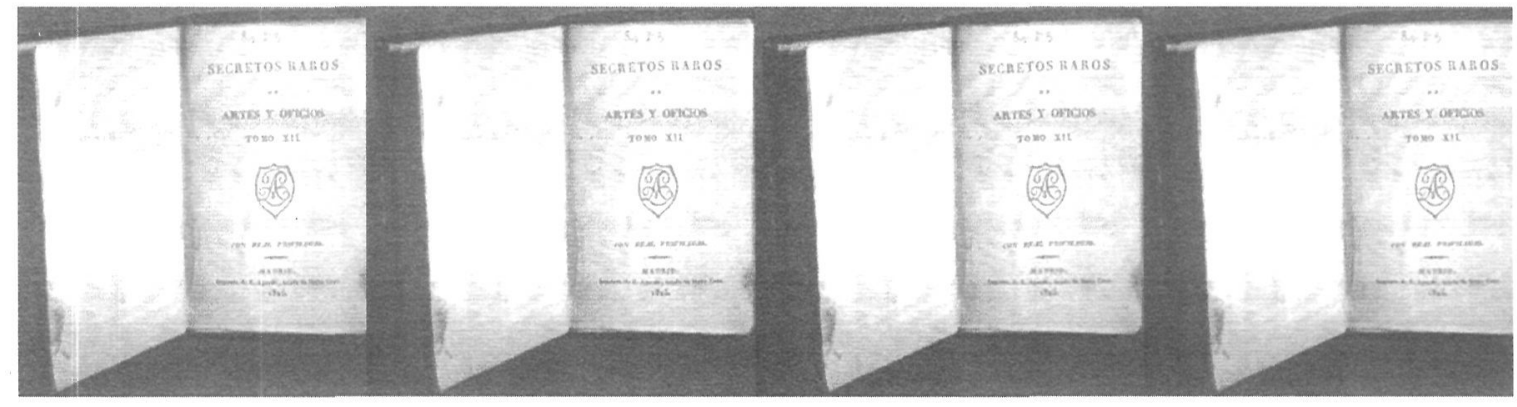

